\title{
SVAR and NLS Model Analysis of US Bank Financial Derivatives and the Related Fields Based on Their Statistical Data
}

\author{
Fengjuan Liu*
}

Wuxi Environmental Science and Engineering Research Center, No.12, Qianou Road, Wuxi City, Jiangsu Province, China, 214153

\begin{abstract}
Today, in many countries, there are many banks engaging in financial derivatives trading to manage risks. This paper selects data on financial derivatives trading from US banks and FRED to analyze the effect of financial derivatives trading on US banks and its economy. The results show that the impact of total financial derivatives trading revenue on bank residual (assets less liabilities) is bigger; an increase in total financial derivatives trading will lead to dramatically rise in bank residual in ten years; a positive change in interest rate derivatives trading has strongly positive impact on bank residual in eleven years; US bank credit don't always expand with the increase in other derivatives (equity and commodity derivatives) trading which is strongly positive in first five years; the change in bank credit represents the feature of convex functions with the grow of total financial derivatives trading and interest rate derivatives; the change in gross government investment represents the characteristic of convex function with the growth of foreign exchange contracts, interest rate derivatives and total financial derivatives trading; an increase in equity and commodity derivatives trading from US banks results in the decrease in U.S. GNP per capita. In a word, more financial derivatives which banking is engaged in are not better.
\end{abstract}

Keywords: Bank residual, financial derivatives, gross government investment, US banks, US economy, U.S. GNP per capita.

\section{INTRODUCTION}

Today, there are many banks and corporations to participate in financial derivatives to hedge business risks. The total amount of interest rate, currency, commodity, and equity contracts at U.S. commercial and savings banks soared from $\$ 6.8$ trillion in 1990 to $\$ 11.9$ trillion in 1993 , an increase of 75 percent [1]. The economies of scale play an important role in the derivatives usage, larger banks are the predominant users of derivatives and the high-growth banks and banks with less liquid assets engage in higher hedging activities [2]. In addition, Purnanandam think that by using derivatives, banks are able to 'insulate' their maturity GAP policy from external shocks. The derivatives business has grown exponentially versus global GDP in sharp contrast to the primary securities on which derivatives are based [3]. Derivatives have become an essential instrument for hedging risks because it enables intermediaries to hedge market risks more efficiently. However, a number of banks actively engaged in derivatives market have had financial difficulties in recent years [4]. Dewally and Shao test how the use of financial derivatives affects banks' informational structure and future stock performance based on a sample of large bank holding companies in the US and find that an increase in the opacity is significantly and positively related to an increase in banks' future stock price crash risk [5]. Rodriguez
Moreno, Mayordomo and Peña think that the banks' holdings of foreign exchange and credit derivatives increase the banks contributions to systemic risk whereas holdings of interest rate derivatives decrease it. However, they also found that credit derivatives seemed to change their role from shock absorbers to shock issuers (2012). Therefore, it is very important for bank risk strategies and national strategies to know about the effect of financial derivatives that bank participate in on banking and one country's economy. In this paper, we select data from Quarterly Report on Bank Derivatives Activities [6] and Federal Reserve Economic Data to analyze the impact.

\section{GLOSSARY OF SPECIFIC TERMS AND THE CAUSALITIES BETWEEN SELECTED INDICATORS}

Bank residual (usaall) refers to assets less liabilities.

The notional amount of total financial derivatives trading (usafdt) includes the notional amount of interest rate derivatives (usair), foreign exchange derivatives (usafec), credit derivatives (usacd) and other derivatives (equity and commodity)(usacoc).

In general, it is proved that one country that has higher level of economic development is heavily dependent on the financial sectors and carries out many government investments to guide the private and enterprise investments. Government investment can promote the improvement of public infrastructure and encourage the investment from enterprises. Therefore, if financial derivatives can promote the develop- 
ment of US commercial banks and its economy, it will increase bank residual, US gross national product per capita (gnppc) and gross government investment (ggi). However, how it goes in the reality of US bank operation?

We select some key indicators such as total financial derivatives trading revenue (tfdtr), usaall, bank credit of all commercial banks (usabccb), gross government investment (usaggi), usagnppc, usacoc, usafdt, usagdp, usagdppc, usafec, swaps and usair as research objects and use methods of granger causality test, cointegration test and NLS to get their causalities between them. The results demonstrate that there are regression relationships between total financial derivatives trading revenue and US bank residual, other derivatives and US bank credit, gross government investment for US and the notional amount of total financial derivatives trading for US commercial banks, bank residual and the notional amount of total financial derivatives from US commercial banks, bank residual and interest rate derivatives trading; gross government investment for US and interest rate derivatives trading or foreign exchange derivatives trading. What's more, it is found that there aren't causalities between usagnppc and tfdtr, usagnppc and usafdt.

\section{THE IMPACT OF FINANCIAL DERIVATIVES TRADING ON US BANKING}

\subsection{The Impact of Total Financial Derivatives Trading Revenue and its Notional Amount on US Bank Residual}

Before the financial crisis during 2007 to 2009, the search for new revenue and profit streams by US banks promoted a long-term disintermediation trend. Derivatives trading might offer an alternative to traditional deposit-taking and lending business as a source of revenue and profit by improving risk management. However, dealing in derivatives creates new forms of systemic risk through complex and opaque patterns of exposure [7]. The return on hedging derivatives is positively associated with the growth in bank's stock returns, whereas trading derivatives' notional value negatively impacts both Tobin's $\mathrm{q}$ and ROAA, and positively impacts risk of the bank's stocks [8]. For US banking, what is the effect of financial derivatives trading on bank residual?

By researches for these data as mentioned before, we found that they are closely related to each other.

In Fig. (1), it is seen that bank residual rapidly rise with increase in total financial derivatives trading revenue. However, during financial crisis, the bank revenue that total financial derivatives trading bring is very small and even negative especially during financial crisis even though they are related to each other. The results indicate that financial derivatives trading will cause the decrease in bank residual during financial crisis or improper financial derivatives trading although increase in total financial derivatives trading revenue lead to the increase in bank residual.

In Fig. (2), it is found that there is linear relationship between US bank residual and financial derivatives trading. The regression model between them is demonstrated in equation 1.

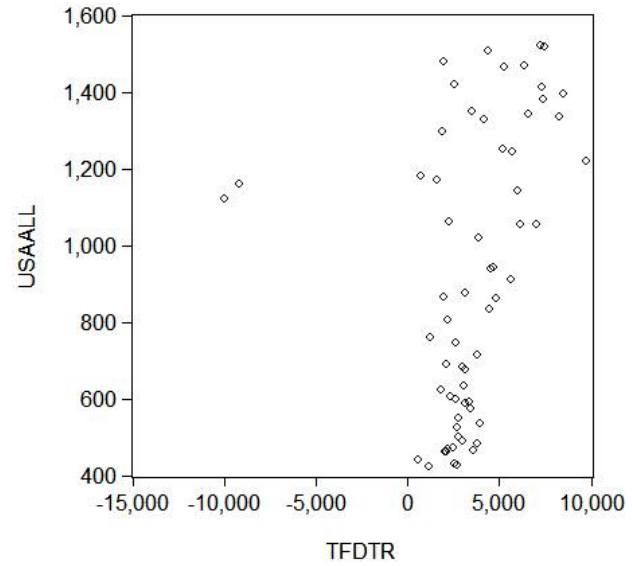

Fig. (1). The scatter diagram between usaall and tfdtr.

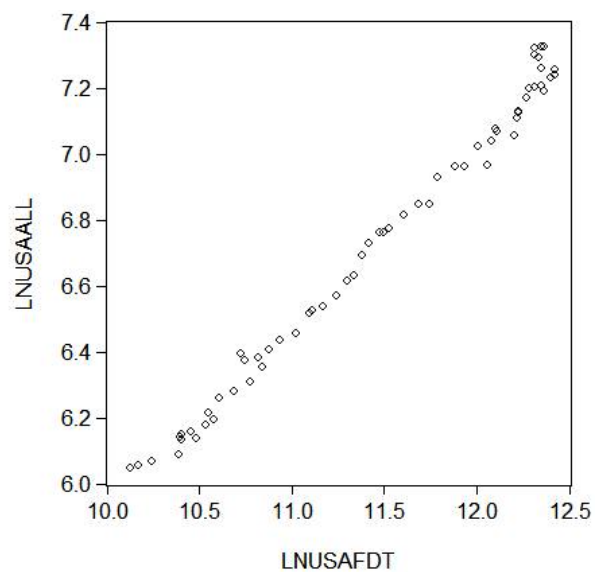

Fig. (2). The relationship graph between usaall and usafdt.

lnusaall $=0.31561+0.55944$ lnusafdt

$$
\begin{gathered}
\text { (1.46979) (30.21663) } \\
\mathrm{R}^{2}=99.47 \% \quad \mathrm{DW}=1.9883
\end{gathered}
$$

The outcome shows that when the notional amount of financial derivatives trading that US banks engaged in increases by $1 \%$, bank residual rises $0.56 \%$. It demonstrates that financial derivatives trading are positively correlated to bank residual.

In order to make clear how long does the response of US bank residual to a change in financial derivatives trading maintain, SVAR model is established. Select long-term response pattern.

\section{Response of LNUSAALL to Shock2}

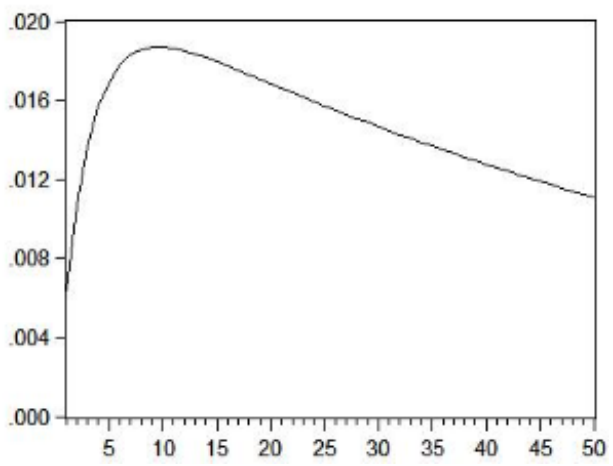

Fig. (3). Response of lnusaall to lnusafdt in SVAR model. 
Table 1. Variance decomposition of LNUSAALL

\begin{tabular}{|c|c|c|c|}
\hline Period & S.E. & Shock 1 & Shock 2 \\
\hline 1 & 0.0196 & 89.52 & 10.48 \\
\hline 2 & 0.0259 & 76.999 & 23.00 \\
\hline 3 & 0.0307 & 63.94 & 36.06 \\
\hline 4 & 0.0350 & 52.53 & 47.47 \\
\hline 5 & 0.0392 & 43.43 & 56.57 \\
\hline 6 & 0.0432 & 36.42 & 63.58 \\
\hline 7 & 0.0470 & 31.08 & 68.92 \\
\hline 8 & 0.0506 & 26.97 & 73.03 \\
\hline 9 & 0.0539 & 23.77 & 76.23 \\
\hline 10 & 0.0571 & 21.25 & 78.75 \\
\hline 11 & 0.0600 & 19.22 & 80.78 \\
\hline 12 & 0.0628 & 17.56 & 82.44 \\
\hline 13 & 0.0655 & 16.19 & 83.81 \\
\hline \multicolumn{4}{|l|}{$\ldots \ldots$} \\
\hline 50 & 0.1101 & 5.74 & 94.26 \\
\hline
\end{tabular}

In Fig. (3), the increase in financial derivatives trading will bring about strongly positive impact on bank residual that equals assets less liabilities in the previous ten years and the response reaches the peak in the tenth year, then the effect becomes smaller and smaller. It indicates that the increase in the bank financial derivatives trading will bring rapid rise of bank residual in the previous ten years and then decrease but maintain the positive effect.

The results in Table 1 suggest that contribution of a positive change of total financial derivatives trading on the bank residual is increasingly on the rise and is the biggest in first six years.

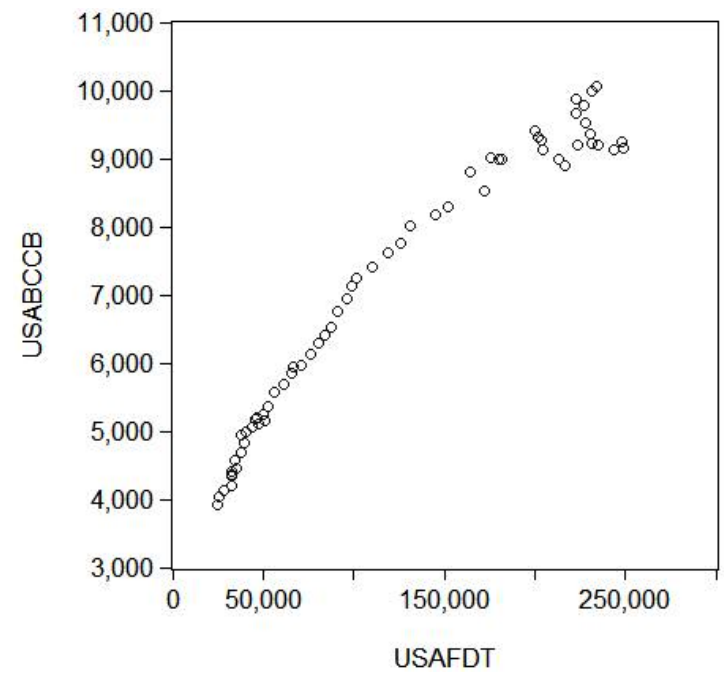

Fig. (4). The scatter diagram between the bank credit and total financial derivatives.

\subsection{The Impact of Financial Derivatives Trading on US Bank Credit}

Bank credit is vital for its sustainable development. The banks with high credit possibly can't get the return even the principle from borrowers when the borrowers face their capital operation. Therefore, these banks will face the possibility of bankruptcy during financial crisis and financial derivatives maybe aggravate this kind of risk that banks face although it has positive impact on bank during the normal time.

Financial derivatives trading are positively related to US bank credit shown in Fig. (4).

Bank credit will gradually enhance with the increase in US bank trading volume of total financial derivatives. However, the increases in bank credit have the feature of convex function.

\subsection{The Impact of Interest Rate Derivatives on US Bank- ing}

The hedging of interest rate risk can increase firm value by lowering the expected transactions cost of bankruptcy [9]. Higher interest rate volatility increases the variance of a firm's cash flows and thus induces higher risk-management incentives, all else remaining equal [2]. The level of interest rate derivatives is positively associated with long-term interest rate exposure (LTIR) but negatively associated with short-term interest rate exposure (STIR) and the positive LTIR exposures are driven by banks with extensive derivative activities [10]. Financial innovations in interest rate derivatives have given banks new and effective instruments for 
Table 2. Variance decomposition of inusaall.

\begin{tabular}{|c|c|c|c|}
\hline Period & S.E. & Shock 1 (Inusaall) & Shock 2 (Inusair) \\
\hline 1 & 0.0196 & 90.81 & 9.19 \\
\hline 2 & 0.0262 & 81.72 & 18.28 \\
\hline 3 & 0.0311 & 71.64 & 28.36 \\
\hline 4 & 0.0352 & 61.96 & 38.04 \\
\hline 5 & 0.0391 & 53.41 & 46.59 \\
\hline 6 & 0.0428 & 46.21 & 53.79 \\
\hline 7 & 0.0464 & 40.30 & 59.70 \\
\hline 8 & 0.0497 & 35.50 & 64.50 \\
\hline 9 & 0.0529 & 31.60 & 68.40 \\
\hline 10 & 0.0560 & 28.42 & 71.58 \\
\hline 11 & 0.0589 & 25.81 & 74.19 \\
\hline 12 & 0.0616 & 23.64 & 76.36 \\
\hline 13 & 0.0641 & 21.84 & 78.16 \\
\hline 14 & 0.0665 & 20.31 & 79.69 \\
\hline 15 & 0.0688 & 19.01 & 80.99 \\
\hline \multicolumn{4}{|l|}{$\ldots \ldots$} \\
\hline 50 & 0.103563 & 8.423510 & 91.58 \\
\hline
\end{tabular}

managing risk and interest rate risk arises from bank operations because banks' assets and liabilities generally have their interest rates reset at different times [1]. Therefore, for US banks, interest rate derivatives trading is closely related to bank residual that is described as assets minus liabilities in equation (2) because of $R^{2}=99.42 \%$.

$$
\text { lnusaall }=0.52138+0.5508 \text { lnusair }
$$

$$
\begin{gathered}
(1.8701) \quad(22.6001) \\
\mathrm{R}^{2}=99.42 \% \quad \mathrm{DW}=2.0344
\end{gathered}
$$

when interest rate derivatives trading rise one percent, US bank residual will increase by $0.55 \%$. It means that interest rate derivatives trading can add the value of bank residual. The response of the banking residual to a change in interest rate derivatives trading in the long run is seen in Fig. (5).

When interest rate derivatives trading are up, bank residual will also dramatically increase and the effect arrives at the peak point, $1.8063 \%$ in the eleventh year, then decrease. It indicates that the impact of interest rate derivatives trading on bank residual is on the up in the first eleven years and on the down after that.

The result in Table 2 demonstrates that contribution of a change in interest rate derivatives trading on bank residual rapidly increases in the previous eleven years.

In addition, interest rate derivatives trading have positive impact on US bank credit shown in Fig. (6).

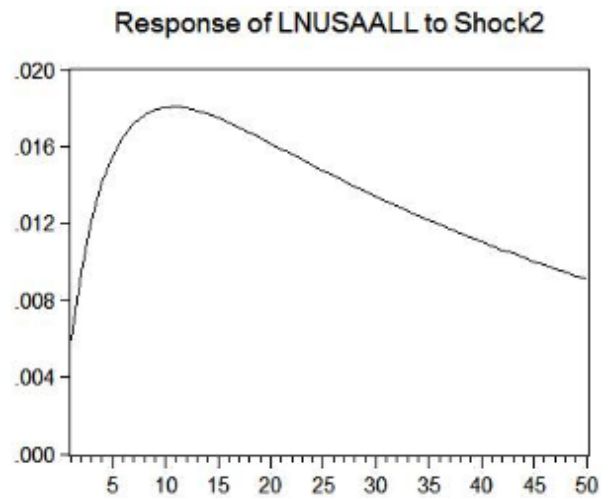

Fig. (5). Response of lnusaall to lnusair in SVAR model.

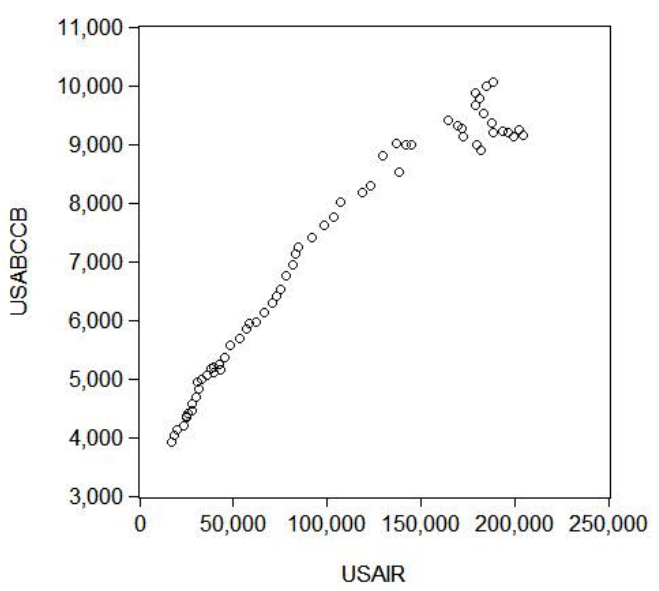

Fig. (6). The scatter diagram between the bank credit and interest rate derivatives. 


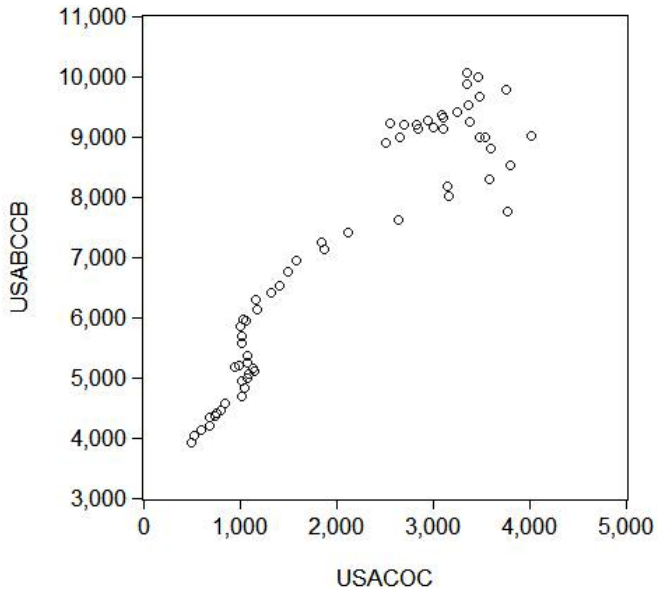

Fig. (7). The scatter diagram between the bank credit and other derivatives.

Similar to Fig. (4), when interest rate derivatives increase shares of contract, bank credit will gradually expand and it has the feature of convex function.

\subsection{The Impact of Other Derivatives (Equity and Com- modity Derivatives) Trading on US Bank Credit}

The aim of financial derivatives trading that US banks engaged in is to mitigate risk to get the best revenue or deduce bank operation loss when they face market fluctuation. Then what will the equity and commodity derivatives trading bring for US banks?

In Fig. (7), we can understand that bank credit didn't always expand with increase in other derivatives trading.
Response of LNUSABCCB to Shock2

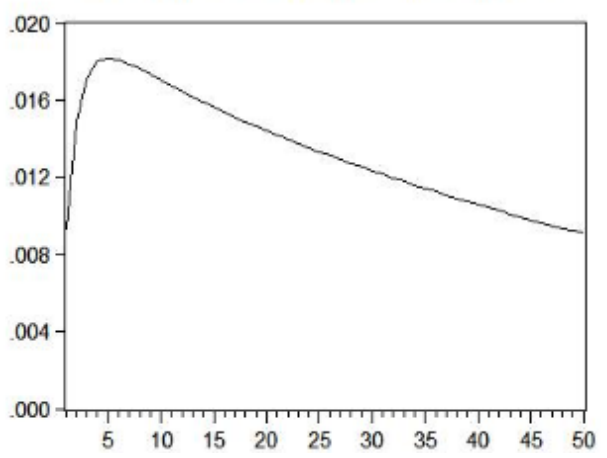

Fig. (8). Response of lnusabccb to lnusacoc in SVAR model.

There is a regression relationship between lnusabccb and lnusacoc. In order to find out the response of bank credit to a change in other derivatives trading in the long run, we used SVAR model to analyze the long-term response.

In Fig. (8), we see, in the long run, that when US banks increase the trading volume of other derivatives, bank credit will dramatically rise in the previous five years and then rapidly decrease. But the effect is always positive even though it is very small. In the fifth year, the response of bank credit to an increase in the trading volume of other derivatives that they involved reaches the top point, $1.82 \%$. It shows that the positive effect of increase in banks participating in other derivatives trading on bank credit is very significant in the previous five years.

By variance decomposition in Table $\mathbf{3}$, the contribution of the positive change of other derivatives trading on bank

Table 3. Variance decomposition of Inusabccb.

\begin{tabular}{|c|c|c|c|}
\hline 1 & 0.0111 & 29.69 & 70.31 \\
\hline 3 & 0.0257 & 8.81 & 91.19 \\
\hline 6 & 0.0408 & 4.95 & 95.05 \\
\hline 7 & 0.0447 & 4.56 & 95.44 \\
\hline 8 & 0.0481 & 4.31 & 95.69 \\
\hline 12 & 0.059 & 3.89 & 96.11 \\
\hline 13 & 0.0613 & 3.85 & 96.15 \\
\hline 14 & 0.0634 & 3.82 & 96.18 \\
\hline \multicolumn{4}{|l|}{...... } \\
\hline 50 & 0.0978 & 3.76 & 96.24 \\
\hline
\end{tabular}


credit is very fast in the first five years and then the rising trend is gradually slow.

\subsection{The Impact of US Bank Financial Derivatives Trad- ing on US Economy}

The aim of OTC derivatives is to disentangle positive from negative effects of derivatives and bank activity on the real economy and restoring the traditional positive link between finance and growth [11]. The growing volume of the derivatives market also significantly contributed to the global financial crisis. After Sipko, J compared the growth of the global nominal and real gross domestic product with the pace of growth of the overall derivatives market, but mainly the over-the-counter market, he found that it is critical to take some measures to eliminate non-transparent transactions with certain derivatives products in order to put the global economy on a sustainable, solid and balanced economic growth path (2011). Then, what is the impact of US bank financial derivatives on US economy?

\subsection{The Impact of Other Derivatives (Equity and Com- modity Derivatives) Trading on Gross National Product Per Capita}

The level of Gross national product per capita reflects the level of one country's economic development. Therefore, the regression relationship between other derivatives trading and gross national product per capita is very important for one country's decision makers to make out the macro and micro economic and financial policies.

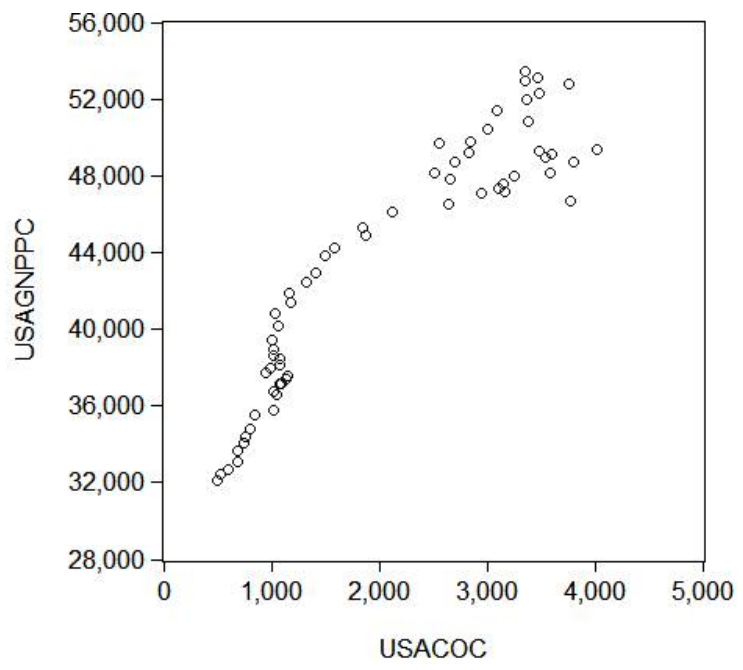

Fig. (9). The scatter diagram between US gross national product per capita and other derivatives.

In Fig. (9), its gross national product per capita for US will rise rapidly with the increase in other derivatives trading and then gradually enter into a stage of slowly growth when the notional amount of other derivatives trading is more than $\$ 1590$ billion or its GNP per capita is above $\$ 44,000$. Therefore, for US banks, more commodities and equities derivatives trading aren't the better [12]. There is non-linear relationship between them as shown in Fig. (9) and the nonlinear regression relationship between lnusagnppc and lnusacoc can be expressed in equation 3 .
Inusagnppc $=6.18577+0.97942 \ln u s a c o c-0.05039(\text { Inusacoc })^{2}$

$$
\mathrm{R}^{2}=93.81 \%
$$

The regression model indicates that an increase in other derivatives trading from US banks didn't always cause the increase in US GNP per capita. When the trading volume of other derivatives from US banks is over a certain amount for the current national power, US GNP per capita will gradually decrease. It presents the characteristic of convex function [13].

In order to analyze the response of US GNP per capita to a change in other derivatives trading in the long term, SVAR model is applied here.

Response of LNUSAGNPPC to Shock2

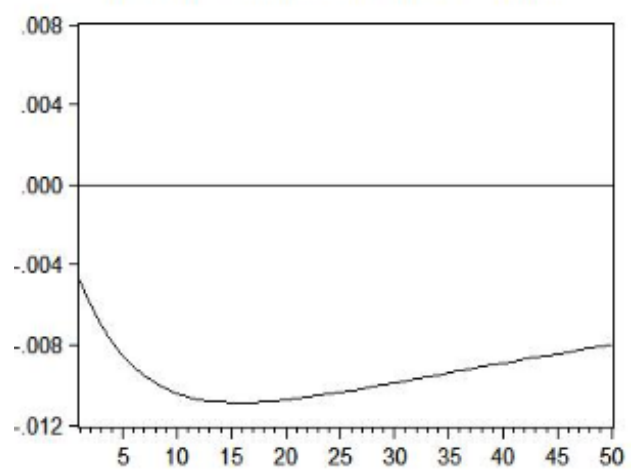

Fig. (10). Response of lnusagnppc to lnusacoc in SVAR model.

In Fig. (10), a positive impulse from other derivatives has a negative impact on the US GNP per capita and reaches its foot value in the sixteenth year. The result demonstrates that US GNP per capita will decrease with the increase of other derivatives trading, that is to say, an increase in equity and commodity derivatives trading lead to a decrease in US GNP per capita. There is adverse effect between them.

In order to understand what the effect of a positive change of other derivatives trading on US GNP per capita in forecasting standard error, the result of structural variance decomposition is shown in Table 4.

When a positive impact from other derivatives trading is exerted to US GNP per capita, in predicting standard error, the contribution of other derivatives trading on US GNP per capita is rapidly increasing in the previous nine years and then gradually become slow. It demonstrates that equity and commodity derivatives trading have bigger impact on US GNP per capital [14-17].

\subsection{The Impact of Total Financial Derivatives Trading on Gross Government Investment}

The higher the level of one country's economic development is, the more its gross government investment is. Government investment can bring the rise in social welfare and enlarge social demands when economy is in the recession. Therefore, knowing about the status of one country's government investment is very important for corporate management. According to the related data, the relationship between the notional amount of total financial derivatives trading and US gross government investment is seen in Fig. (11). 
Table 4. Variance decomposition of LNUSAGNPPC.

\begin{tabular}{|c|c|c|c|}
\hline Period & S.E. & Shock 1 & Shock 2 \\
\hline 1 & 0.006996 & 52.29777 & 47.70223 \\
\hline 2 & 0.010098 & 41.38852 & 58.61148 \\
\hline 3 & 0.012725 & 32.55282 & 67.44718 \\
\hline 4 & 0.015170 & 25.70775 & 74.29225 \\
\hline 5 & 0.017516 & 20.51687 & 79.48313 \\
\hline 6 & 0.019789 & 16.60822 & 83.39178 \\
\hline 7 & 0.021993 & 13.66094 & 86.33906 \\
\hline 8 & 0.024130 & 11.42462 & 88.57538 \\
\hline 9 & 0.026197 & 9.712535 & 90.28747 \\
\hline 10 & 0.028192 & 8.388226 & 91.61177 \\
\hline 11 & 0.030114 & 7.352660 & 92.64734 \\
\hline 12 & 0.031963 & 6.533903 & 93.46610 \\
\hline 13 & 0.033740 & 5.879466 & 94.12053 \\
\hline 14 & 0.035447 & 5.350775 & 94.64923 \\
\hline 15 & 0.037085 & 4.919247 & 95.08075 \\
\hline 16 & 0.038657 & 4.563520 & 95.43648 \\
\hline \multicolumn{4}{|l|}{$\ldots \ldots$} \\
\hline 25 & 0.050247 & 3.027986 & 96.97201 \\
\hline 26 & 0.051298 & 2.946935 & 97.05307 \\
\hline \multicolumn{4}{|l|}{$\ldots \ldots$} \\
\hline 50 & 0.068119 & 2.173618 & 97.82638 \\
\hline
\end{tabular}

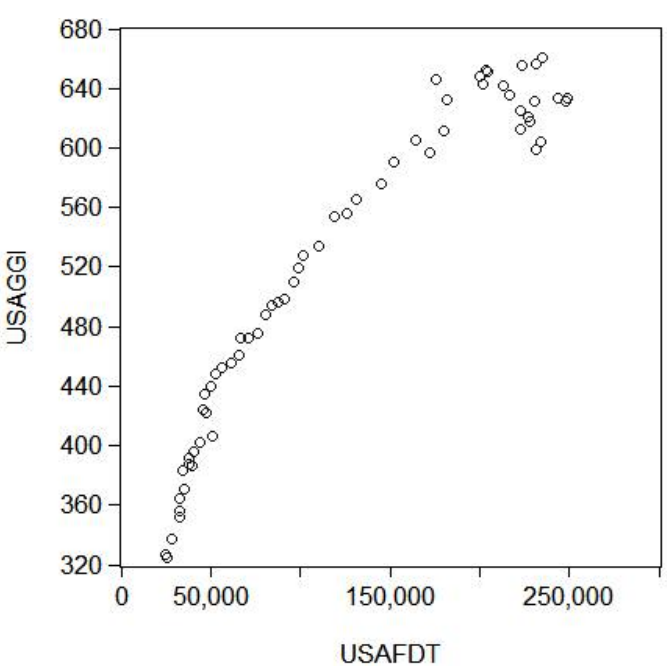

Fig. (11). The scatter diagram between US gross government investment and total financial derivatives trading.

As shown in Fig. (11), from 1997 to 2013, gross government investment will increase with the growth of the notional amount of US bank financial derivatives trading.
However, the trend of growth is gradually slowing and even the downward trend comes out as described in the equation 4.

usaggi $=-205.2137+72.0388 \sqrt[5]{u s a f d t}$

When the trading volume of bank financial derivatives increases from 25000 billion to 183000 billion, gross government investments will rapidly increase. It implies that an increase in U.S. bank financial derivatives trading will lead to the increase in gross government investments and gross government investment has the feature of convex function.

\subsection{The Impact of US Banks Foreign Exchange Deriva- tives Trading on US Gross Government Investment}

$\mathrm{Au}$ Yong, Faff and Chalmers suggest that there isn't any significant association between banks' derivative activities and exchange rate exposure (2009). However, US government investment programs cover many fields including education, culture, social security, medical treatment, transportation, housing and city planning, agriculture and forestry industry, government office premises, military and defense infrastructure, etc. many fields are directly and indirectly related to technology, funds and raw material and so on be- 
cause they have cooperation with overseas business or some of their branch sectors. By testing US historical data, we found that there is non-linear relationship between foreign exchange derivatives trading from US banks and US gross government investment.

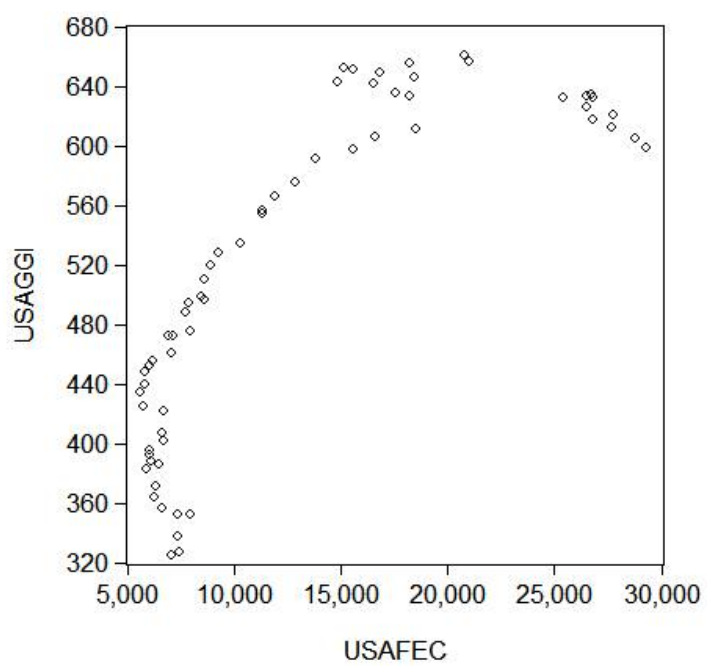

Fig. (12). The scatter diagram between US gross government investment and foreign exchange derivatives.

As seen in Fig. (12), when the notional amount that US banks invest foreign exchange derivatives varies from 5700 billion to 7500 billion, gross government investment is lower than 480 billion; when the value of GGI is higher than 480 billion, the notional amount that the bank invests foreign exchange derivatives will gradually increase and then decrease; when the notional amount of foreign exchange contracts amount to 20824 billion, gross government investment reaches the peak. However, when financial crisis take place, there is reverse relationship between them. Therefore, there is non-linear relationship between usaggi and usafec as expressed in equation 5 .

There is causality between usaggi and usafec.

$$
\begin{aligned}
\text { usaggi }= & 431.39166-6.86271 \sqrt{\text { usafec }}+48.40706 \sqrt[3]{\text { usafec }} \\
& (1.70751) \quad(-2.21208) \quad(2.09089) \\
& \mathrm{R}^{2}=99.44 \% \quad \mathrm{DW}=1.8974
\end{aligned}
$$

The result indicates that an increase in bank foreign exchange contract will result in the increase in gross government investment. However, when it arrives at a certain point, the effect is negative. Here, gross government investment represents the strong characteristics of convex function.

\subsection{The Impact of US Banks Interest Rate Derivatives on US Gross Government Investment}

The change in bank interest rate will have a great influence on social investment because it involves business operation cost, investment profits, etc. So is government investment because the level of interest rate will lead to the level of bank and government operation cost, amount of bank savings, the profits from public assets and capital operation. Therefore, financial innovation about interest rate derivatives has a bigger effect on gross government investment.

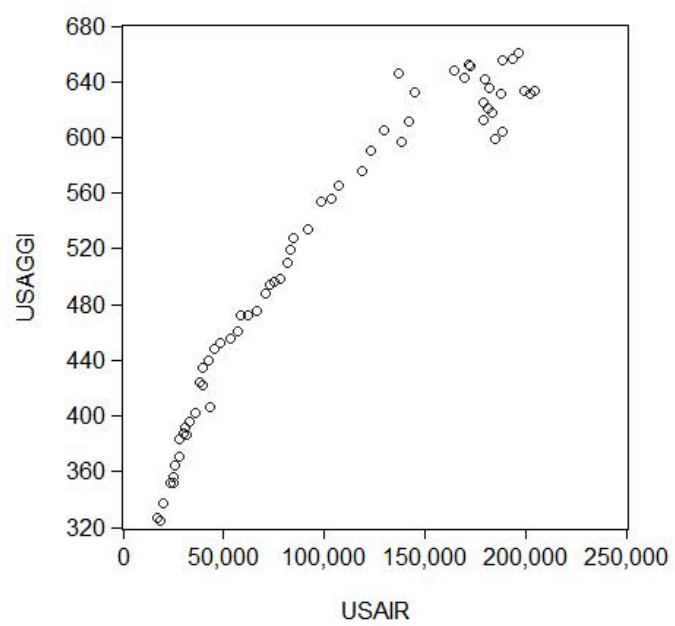

Fig. (13). The scatter diagram between US gross government investment and interest rate derivatives trading.

As shown in Fig. (13), from 1997 to 2013, gross government investment has rapid growth with the increase of the amount of US banks interest rate derivatives trading. However, the trend of growth gradually slow down and even is on the decline. The trend can be described in equation 6 .

usaggi $=80.40117+9.89026 \sqrt[3]{\text { usair }}$

when the notional amount of US banks interest rate derivatives trading increases from 17000 billion to 107420 billion, gross government investments will rapidly increase and then, slowly grow, then decrease. It shows in equation 6 that an increase in U.S. bank financial derivatives trading will lead to the increase in gross government investments. However, when interest rate derivatives trading reach a certain amount, gross government investment will move to the opposite direction.

\section{CONCLUSION}

The impact of total financial derivatives trading revenue on the bank residual is bigger; an increase in total financial derivatives trading will lead to the dramatically rise in the bank residual in ten years; a positive change of interest rate derivatives trading have strongly positive impact on the bank residual in eleven years; the bank credit didn't always expand with increase in equity and commodity derivatives trading which is strongly positive in first five years; the change in the bank credit shows the feature of convex functions with the grow of total financial derivatives trading and interest rate derivatives trading; the increase in equity and commodity derivatives trading from US banks will result in the decrease in US GNP per capita; gross government investment represents the feature of convex function with the growth of foreign exchange contracts, interest rate derivatives and total financial derivatives trading. In short, more financial derivatives which banking is engaged in are not better.

\section{CONFLICT OF INTEREST}

The author confirms that this article content has no conflict of interest. 


\section{ACKNOWLEDGEMENTS}

Authors wishing to acknowledge professors who taught Derivatives in Michigan State University. This work is supported by Program of Jiangsu Overseas Research\&Training Program for University Prominent Young\&Middle-aged Teachers and Presidents, China (2012) and Wuxi Environmental Science and Engineering Research Center.

\section{REFERENCES}

[1] K. Simons, "Interest rate derivatives and asset-liability management by commercial banks," International Advances in Economic Research, vol. 1, no. 1, pp. 83-83, 1995.

[2] A.Purnanandam, "Interest rate derivatives at commercial banks: An empirical investigation," Journal of Monetary Economics, vol. 54, no. 6, pp. 1769-1808, 2007.

[3] A. Blundell-Wignall, and P. Atkinson, "Global SIFIs, derivatives and financial stability," OECD Journal: Financial Market Trends, no. 1, pp. 167-200, 2011.

[4] J. Peek, and E. S. Rosengren, "Derivatives activity at troubled banks". Journal of Financial Services Research, vol. 12, no. 2-3, pp. 287-302, 1997.

[5] M. Dewally, and Y. Shao, "Financial derivatives, opacity, and crash risk: Evidence from large US banks," Journal of Financial Stability, vol. 9, no. 4, pp. 565-577, 2013.

[6] Quarterly Report on Bank Derivatives Activities (1997-2013). http://www.occ.treas.gov/topics/capital-markets/financialmarkets/trading/derivatives/derivatives-quarterly-report.html

[7] D. Ashraf, and J. Goddard, "Derivatives in the wake of disintermediation: a simultaneous equations model of commercial and indus- trial lending and the use of derivatives by US banks," International Journal of Banking, Accounting and Finance, vol. 4, no. 3, pp. 250271, 2012.

[8] N. Gomayun, H.Penikas, and Y. Titova, "Do Hedging and Trading Derivatives Have the Same Impact on Public European Banks' Value and Share Performance?," National Research University Higher School of Economics Research Paper BRP, vol. 9, 2012.

[9] C. W. Smith, and R. M. Stulz, "The determinants of firms' hedging policies," Journal of financial and quantitative analysis, vol. 20, no. 4, pp. 391-405, 1985.

[10] H. H. A. Yong, R.Faff, and K.Chalmers, "Derivative activities and Asia-Pacific banks' interest rate and exchange rate exposures," Journal of international financial markets, institutions and money, vol. 19, no. 1, pp. 16-32, 2009.

[11] L. Becchetti, and N. Ciampoli, "What is new in the finance-growth nexus: OTC derivatives, bank assets and growth," EconomEtica working paper series, WP, no. 40, 2012.

[12] M. Rodriguez-Moreno, S. Mayordomo, and J. I. Peña, "Derivatives Holdings and Systemic Risk in the US Banking Sector," School of Economics and Business Administration, University of Navarra, Available at SSRN 1973953, 2012.

[13] J. Sipko, "Derivatives and the real economy," Creative and Knowledge Society, vol. 1, no. 1, pp. 33-43, 2011.

[14] Bank Credit of All Commercial Banks. from http://research. stlouisfed.org/fred2/series/TOTBKCR/downloaddata?cid=33078

[15] Gross government investment. From http://research.stlouisfed.org/ fred2/series/A782RC1Q027SBEA/downloaddata?cid=33023

[16] Residual (Assets Less Liabilities), All Commercial Banks from http://research.stlouisfed.org/fred2/series/RALACBM027SBOG/do wnloaddata? $\mathrm{cid}=33078$

[17] Gross National Product per capita. from http://research.stlouisfed. org/fred2/series/A791RC0Q052SBEA/ downloaddata?cid=106

Received: June 10,2015

Revised: July 29, 2015

Accepted: August 15, 2015

(C) Fengjuan Liu; Licensee Bentham Open.

This is an open access article licensed under the terms of the (https://creativecommons.org/licenses/by/4.0/legalcode), which permits unrestricted, noncommercial use, distribution and reproduction in any medium, provided the work is properly cited. 